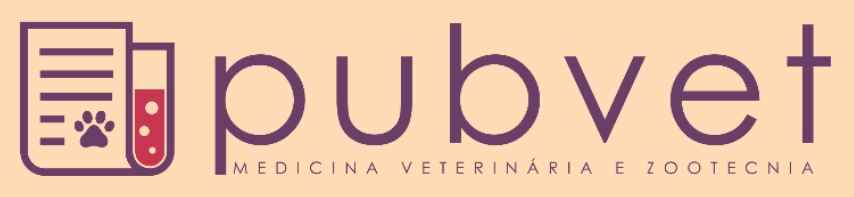

https://doi.org/10.31533/pubvet.v12n11a207.1-8

\title{
Importância do vírus da leucemia felina na linfomagênese: Revisão
}

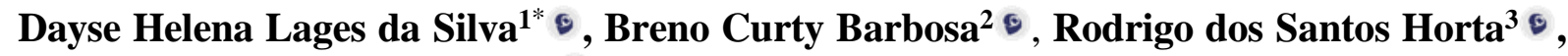 \\ Fabiola de Oliveira Paes Leme ${ }^{4}$ 。
}

${ }^{I}$ Mestranda em Ciência Animal da Universidade Federal de Minas Gerais, Departamento de Clínica e Cirurgia Veterinárias. Belo Horizonte - MG Brasil. ${ }^{2}$ Doutorando em Ciência Animal da Universidade Federal de Minas Gerais, Departamento de Clínica e Cirurgia Veterinárias. Belo Horizonte -MG Brasil. ${ }_{3}^{3}$ Docente da Universidade de Vila Velha, Departamento de Medicina Veterinária. Vila Velha - ES Brasil.

${ }^{4}$ Docente da Universidade Federal de Minas Gerais, Departamento de Clínica e Cirurgia Veterinárias. Belo Horizonte - MG Brasil.

*Autor para correspondência, E-mail: daysehlages@gmail.com

RESUMO. O vírus da Leucemia felina (FeLV) é um retrovírus oncogênico frequentemente relacionado ao linfoma em felinos domésticos. O principal mecanismo pelo qual o FeLV induz neoplasia é através da mutagênese insercional adquirida somaticamente, podendo o provirus integrado ativar proto-oncogenes ou interromper um gene supressor de tumor. $\mathrm{O}$ principal proto-oncogene alterado pelo FeLV é o c-myc. Esta revisão tem como objetivo elucidar um dos principais mecanismos pelos quais o FeLV está associado ao linfoma em felinos domésticos.

Palavras chave: FeLV, infecção, gatos, oncogene, mutagênese insercional, linfoma

\section{Importance of feline leukemia virus in lymphomagenesis: Review}

\begin{abstract}
Feline Leukemia virus (FeLV) is an oncogenic retrovirus often related to lymphoma in domestic cats. The main mechanism by which FeLV induces neoplasia is through somatically acquired insertional mutagenesis, and the integrated provirus can activate proto-oncogenes or disrupt a tumor suppressor gene. The major proto-oncogene altered by FeLV is $c$-myc. This review aims to elucidate one of the main mechanisms by which FeLV is associated with lymphoma in domestic cats.
\end{abstract}

Keywords: FeLV, infection, cats, oncogene, insertional mutagenesis, lymphoma

\section{Importancia del virus de la leucemia felina en la linfomagénesis: Revisión}

RESUMEN. El virus de la leucemia felina (FeLV) es un retrovirus oncogénico frecuentemente relacionado con el linfoma en los felinos domésticos. El principal mecanismo por el cual el FeLV induce neoplasia es a través de la mutagénesis insertiva adquirida somáticamente, pudiendo el provirus integrado activar proto-oncogenes o interrumpir un gen supresor de tumor. El principal proto-oncogene alterado por el FeLV es el $c-m y c$. Esta revisión tiene como objetivo elucidar uno de los principales mecanismos por los cuales el FeLV está asociado al linfoma en felinos domésticos.

Palabras clave: FeLV, infección, gatos, oncogén, mutagénesis insertiva, linfoma

\section{Introdução}

A FeLV acarreta à disfunção imunológica e infecções oportunistas, hipoplasia medular eritróide e/ou megacariocítica, hiperplasia neutrofílica ineficaz, mielodisplasias, mielofibrose, doenças imunomedias (anemia hemolítica imunomediada, trombocitopenia, glomerulonefrite, poliartrite, uveíte), linfadenopatia periférica, alterações neurológicas, falha reprodutiva e gastrintestinal. $\mathrm{O}$ desenvolvimento de neoplasias como linfoma, leucemia e fibrossarcomas acometem aproximadamente $23 \%$ dos gatos (Sykes \& Hartmann, 2013). 
O câncer ocorre quando há alteração dos processos que controlam o crescimento e a proliferação celulare. A integração do provírus do FeLV no genoma do hospedeiro pode atuar como um mutagênico insercional e alterar o controle de crescimento das células (Rezanka et al., 1992). O linfoma é a neoplasia hematopoiética mais comum em gatos, com incidência de 200 casos a cada 100.000 gatos (Dorn, 1967; Hardy Junior, 1981). $\mathrm{Na}$ década de 70 , cerca de $70 \%$ dos linfomas felinos foram associados à infecção progressiva pelo FeLV, nos EUA (Rojko et al., 1989).

O controle do FeLV tem sido considerado bem sucedido devido as mudanças nas práticas de Manejo envolvendo identificação e isolamento de gatos infectados e seguidas pelo desenvolvimento de vacinas contra o FeLV (Hardy Junior et al., 1976; Hoover \& Mullins, 1991; Hoover et al., 1991; Poulet et al., 2003; Weijer et al., 1986). Como resultado, a prevalência global de infecção por FeLV diminuiu e, com isso, a população em risco de linfoma associado ao FeLV também (Gleich \& Hartmann, 2009; Gleich et al., 2009; Levy et al., 2006).

Sorologias realizadas em São Paulo e no Rio de Janeiro mostraram que a prevalência do FeLV varia de 12,5 a $20,3 \%$, respectivamente (Hagiwara et al., 2015; Souza et al., 2002). Em Belo Horizonte, por método de reação em cadeia de polimerase (PCR), 47,5\% da população de gatos estão infectados pelo vírus do FeLV (Coelho et al., 2011). Dentro deste contexto de importância epidemiológica e morbidade, objetiva-se elucidar o papel do FeLV na linfomagênese, através do mecanismo da mutagênese insercional.

\section{Vírus da leucemia felina (FeLV)}

O vírus da leucemia felina (FeLV) é um gammaretrovírus membro da subfamília Oncornavirus envelopado, com RNA de fita simples e contém a enzima transcriptase reversa (RT) (Hartmann, 2005). O genoma do FeLV contém três genes: o gene envelope (env), que realiza a codificação para a glicoproteína de superfície gp70 e a proteína transmembrana p15E; o gene polimerase $(\mathrm{pol})$, que realiza codificação para a transcriptase reversa, protease e integrase; e o gene de antígeno específico do grupo ( $g a g)$, que codifica proteínas internas do vírus, incluindo a proteína nucleocapsídeo p27 (Coffin, 1979).

$\mathrm{O}$ gato doméstico possui um gammaretrovirus endógeno, semelhante ao FeLV, naturalmente incorporado em seu genoma, que não é transmitido horizontalmente: o vírus da leucemia felina endógeno (enFeLV). Esse retrovírus endógeno, não patogênico, é herdado pela transmissão da mãe para o filhote pela linha germinal. Essas frações endógenas de DNA proviral não produzem partículas virais infecciosas, estão presentes em todas as células do felino, mas não se replicam. Sua relevância principal se baseia no fato de que estas frações de DNA podem, potencialmente, recombinar com o DNA proviral do FeLV-A (único subtipo contagioso), dando origem aos demais subtipos do FeLV (B, C e T), antigenicamente relacionados, mas com patogênese distinta e classificados de acordo com os receptores celulares específicos e as respostas as suas ações mutagênicas (Lutz et al., 2009; Soe et al., 1983). O subtipo A é onipresente e está envolvido em todas as infecções. O subtipo B origina-se da recombinação do FeLV-A com enFeLV. O subtipo C é uma mutação do gene env, e o subtipo $\mathrm{T}$ é definido pelo seu linfotropismo pelos linfócitos T (Lutz et al., 2009).

O FeLV-A é minimamente patogênico na ausência de outras variantes. Entretanto, a replicação defeituosa devido a uma mutação no gene env, pode induzir a síndrome da imunodeficiência (Mullins et al., 1986; Overbaugh et al., 1988). O FeLV-C pode estar exclusivamente associado ao desenvolvimento de aplasia pura de células vermelhas. Os isolados de FeLV-B parecem estar associados a uma variedade de propriedades patogênicas. A forma predominante é o linfoma mediastinal, onde anemia não regenerativa e variedades de neoplasias linfoides e leucemias mieloides agudas também são documentadas para o subtipo B (Fujino et al., 2008).

A principal via de transmissão do FeLV-A é por secreção oro nasal contendo o vírus. Altas cargas do FeLV estão presentes na saliva de gatos virêmicos (Francis et al., 1979; Gomes-Keller et al., 2006). Embora o vírus seja relativamente instável no meio ambiente, a transmissão pela saliva é facilitada devido ao comportamento social dos felinos, como hábitos de higiene mútua por lambedura, partilha de tigelas de alimentação ou por meio de brigas (Francis et al., 1979).

A transmissão iatrogênica também pode ocorrer, geralmente pelo uso de agulhas, instrumentos, fômites ou transfusões de sangue contaminados (Hartmann, 2005; Hartmann, 2012a; Hartmann, 2012b). A transmissão transplacentária ocorre caso a fêmea infectada 
esteja na fase virêmica, no momento da concepção, podendo resultar em morte embrionária, natimortos ou filhotes virêmicos (Pacitti et al., 1986)et al., 1986). Em fêmeas com infecção latente, o vírus não é transmitido pelo útero, podendo o filhote se infectar com o leite ou saliva maternos após o nascimento (Lutz et al., 2009).

O FeLV se replica dentro de muitos tecidos, incluindo medula óssea, glândulas salivares e epitélio respiratório. Caso, a resposta imune não intervenha após a infecção inicial, o FeLV se espalha e infecta as células precursoras hematopoiéticas. O genoma de RNA de cadeia simples é transcrito de forma reversa para o DNA, que é integrado aleatoriamente no genoma celular do hospedeiro, sendo o DNA integrado chamado de "provírus" (Hartmann, 2005; Hartmann, 2012b).

\section{Patogênese}

A patogênese do FeLV desde a infecção, até a eliminação viral, pode ser descrita em seis estágios. No estágio I, ocorre o contato do vírus com as células hospedeiras, primariamente nos linfócitos presentes na faringe e tonsilas nos primeiros dois dias após a exposição oro nasal ao vírus. Em seguida (estágio II) o vírus é amplificado nos nódulos linfáticos e o FeLV é transportados através de linfócitos e macrófagos para locais secundários (medula óssea e ao tecido linfoide associado ao intestino - GALT) (Rojko \& Olsen, 1984). A proliferação do FeLV em locais distantes da inoculação como baço, nódulos linfoides e GALT ocorre entre 3 e 12 dias (estágio III). O estágio IV, por sua vez, envolve a replicação viral na medula óssea, em precursores de neutrófilos e plaquetas, e no epitélio das criptas intestinais (7-21 dias). No estágio $\mathrm{V}$ ocorre infecção de neutrófilos e plaquetas circulantes e estabelecimento da viremia entre 14 e 28 dias. Entre 28 e 56 dias ocorre infecção epitelial generalizada e excreção do vírus, correspondendo ao estágio VI (Rojko et al., 1979). A infecção é geralmente estabelecida cerca de duas a seis semanas após a exposição ao vírus. Se não houver uma resposta imune eficiente nessa fase da infecção, existe o potencial de produção maciça de vírus e o estabelecimento de uma viremia persistente. A viremia persistente de origem na medula óssea é geralmente estabelecida cerca de quatro a seis semanas após a infecção. Tanto o vírus livre quanto o celular estão presentes no sangue, e há disseminação da infecção para múltiplos tecidos glandulares e epiteliais, incluindo as glândulas salivares e a mucosa da faringe e nasal, levando à disseminação oro nasal do vírus e ao potencial de transmissão (Sparkes, 1997).

A imunidade para o FeLV é construída através da produção de títulos protetores de anticorpos de neutralização do vírus direcionados contra o epitopo da glicoproteína do envelope viral gp70, que impede que o mesmo se ligue a célula hospedeira, eliminandoo vírus da corrente sanguínea (Rojko \& Kociba, 1991; Rojko \& Olsen, 1984). A maioria dos filhotes é protegido por anticorpos maternos até a idade de seis semanas. Filhotes infectados no útero ou infectados no período de transição, entre seis a 14 semanas de vida, podem não ser capazes de responder eficazmente à infecção viral e uma proporção significativa desses animais torna-se persistentemente infectados. Gatos adultos expostos a doses muito altas de vírus também podem se tornar persistentemente infectados, especialmente em grandes colônias onde a doença se torna endêmica.

A explicação pela qual gatos mais velhos tornam-se mais resistentes ao vírus se deve ao número de receptores celulares necessários para o FeLV-A entrar nas células-alvo, como linfócitos e macrófagos, que parece diminuir nesses gatos e, assim, o estabelecimento da infecção torna-se mais difícil (Hartmann, 2005; Hartmann, 2012a; Hartmann, 2012b).

$\mathrm{O}$ antígeno de membrana celular de oncornavírus felino (FOCMA) é um antígeno presente na superfície de células transformadas (Essex \& Snyder, 1973), sendo considerado o primeiro antígeno celular expresso a partir da infecção por FeLV ou transformação tumoral (Essex et al., 1975; Snyder et al., 1978). O desenvolvimento de grandes quantidades de anticorpos contra FOCMA poderia proteger contra o desenvolvimento de linfomas induzidos por FeLV por lise dependente do complemento de células tumorais (Cotter et al., 1975; Essex et al., 1975; Grant et al., 1980). Os anticorpos antiFOCMA indicam exposição ao FeLV e podem fornecer um mecanismo protetor contra $o$ desenvolvimento do tumor (Hartmann, 2005; Hartmann, 2012a; Hartmann, 2012b).

\section{Estágios da infecção}

Infecção abortiva: Alguns gatos imunocompetentes podem desenvolver uma 
imunidade humoral e celular efetivas, limitando a replicação viral ao tecido linfoide na região da orofaringe, dessa forma esses gatos não se tornam virêmicos e apresentam altos níveis de anticorpos neutralizantes. Tanto o antígeno viral quanto o RNA viral e DNA proviral não são detectados no sangue. A infecção abortiva provavelmente ocorre quando o gato é exposto a baixas doses do vírus (Hartmann, 2005; Hartmann, 2012a; Hartmann, 2012b).

Infecção Regressiva: Alguns gatos desenvolvem uma resposta imune eficaz contra a replicação do vírus e a viremia é contida antes ou logo após a infecção da medula óssea. Essa é conhecida como infecção regressiva. Depois da infecção inicial, o vírus replica e propaga sistematicamente através da infecção de linfócitos e monócitos. Nesse estágio, o gato pode ter resultado positivo nos testes que detectam o antígeno viral no plasma sanguíneo, como o ELISA. Em alguns gatos, a viremia pode persistir por mais de três semanas. Após este período, as células da medula óssea podem ser infectadas como as células precursoras hematopoiéticas e produzir granulócitos e plaquetas infectadas (Hartmann, 2005; Hartmann, 2012a; Hartmann, 2012b).

Uma certa porcentagem de gatos é capaz de depurar a viremia, e embora não haja eliminação do vírus, a informação para a replicação do vírus (o seu DNA proviral) está presente nas células tronco da medula. Essa condição é chamada de "infecção latente". Embora o DNA proviral permaneça presente dentro do genoma celular, nenhum vírus é produzido ativamente, porque uma resposta imunológica eficiente restringe a replicação e a expressão do vírus. A infecção regressiva pode ser reativada, devido a informação para produção de partículas virais completa que está presente no genoma do gato (Hartmann, 2012a; Hartmann, 2012b).

Infecção progressiva: Gatos com infecção progressiva são persistentemente virêmicos. Ocorre extensiva replicação viral, primeiro em tecidos linfoides, seguido pela medula óssea, mucosa e epitélio glandular. A infecção regressiva e a progressiva podem ser distinguidas através de testes rápidos para pesquisa do antígeno viral no sangue periférico. Na infecção regressiva os gatos tornam-se negativos no máximo 16 semanas após a infecção, enquanto na infecção progressiva os gatos infectados permanecem positivos ( as infecções do DNA proviral do FeLV é detectado no sangue pela reação em cadeia de polimerase (PCR). Mas, quando mensurado no PCR quantitativo a carga viral da infecção regressiva é baixa, enquanto na infecção progressiva a carga viral é alta (Pepin et al., 2007; Torres et al., 2005).

Infecção focal: A replicação viral atípica persistente, como na glândula mamária, bexiga e olhos pode ser considerada focal ou atípica. Essa replicação pode levar a uma produção intermitente de antígenos, além disso, esses gatos podem ter resultados fracamente positivos ou discordantes na pesquisa de antígenos, ou podem alternar entre resultados positivos e negativos (Levy et al., 2008).

\section{Linfomagênese viral}

A infecção progressiva do FeLV está associada a indução de várias doenças degenerativas e proliferativas na linhagem de células hematopoiéticas em gatos (Linenberger \& Abkowitz, 1995; Rohn et al., 1997; Roy-Burman, 1996). O FeLV aumenta 62 vezes o risco de linfoma em gatos infectados, por isso é considerado o vírus mais importante conhecido como indutor de tumor em felinos (Rezanka et al., 1992; Shelton et al., 1990). Alguns estudos evidenciam a ocorrência de linfomas em gatos na infecção regressiva, Um estudo realizado por Jackson et al. (1993) apontaram que, dos 70 casos de linfomas em gatos, $30 \%$ eram negativos para o antígeno viral e positivos em PCR, as hipóteses apontadas pelos autores seria a presença de uma infecção latente por FeLV, bem como a presença de um vírus recombinante defeituoso, a presença de apenas uma porção do genoma do FeLV, que também o torna defeituoso na replicação, ou um fenômeno de "batida e corrida", de tal forma que o FeLV induz linfoma, mas não se integra ao genoma da célula hospedeira.

A infecção da célula hospedeira é iniciada pelo reconhecimento celular do receptor para a glicoproteína do envelope (gp70). O núcleo viral é internalizado e as duas cópias do genoma do RNA de cadeia simples e senso positivo são liberadas. O RNA viral é dependente da DNA polimerase, transcriptase reversa, que faz uma cópia de DNA do genoma viral, conhecido como provírus. $\mathrm{O}$ provírus se integra ao genoma do hospedeiro, ladeado por repetições terminais longas (LTR) são uma série de nucleotídeos derivados da extremidade 5' e 3' do RNA viral. Dentro da 
região U3 da LTR estão as sequências promotoras e potenciadoras que controlam a transcrição do gene viral. $\mathrm{O}$ provírus forma o modelo para a produção de novos viriões - vírus (Beatty, 2014).

Os tumores induzidos pelo FeLV são causados, pelo menos em parte, pela mutagênese insercional adquirida somaticamente (Forman et al., 2009). $\mathrm{Na}$ mutagênese insercional o retrovírus é integrado próximo ao gene celular, como um proto-oncogene, a transcrição do gene pode ser regulada positivamente pela região U3 da LTR retroviral, cuja função promotora e intensificada são elementos necessários para a expressão do gene viral. Por outro lado, se a integração foi no gene supressor de tumor, a transcrição pode ser alterada ou interrompida, então a célula adquire vantagens para o crescimento descontrolado (Fujino et al., 2008).

Os proto-oncogenes codificam uma variedade de proteínas, tais como fatores do crescimento, receptores de fatores do crescimento e proteínas quinases, cuja ativação inadequada favorece a proliferação celular (Tsatsanis et al., 1994).

Análises moleculares do linfoma associado ao FeLV têm identificado Sítios de Integração Comum (SIC), que favorecem a integração do próvirus e influenciam na expressão de um protooncogene próximo, resultando em vantagens de sobrevivência a célula. Os principais locus para SIC no linfoma associado ao FeLV são $c-m y c$, flvi1, flvi-2, fit-1, pim-1 e flit-1 (Fujino et al., 2008).

O primeiro SIC do FeLV descrito, resulta em alterações na expressão e organização do protooncogene $c$-myc. O produto da proteína myc é uma fosfoproteína (Hann et al., 1983; Ramsay et al., 1982) nuclear (Abrams et al., 1982; Persson \& Leder, 1984; Ramsay et al., 1982) que desempenha um papel na progressão do ciclo, apoptose e transformação celulares.

Duas alterações do myc têm sido descritas em linfomas associados ao FeLV: integração e transdução. As transformações nas células pelo gene myc podem ser, devido a desregulação de sua expressão. Isso ocorre pela alteração do protooncogene $m y c$, devido a integração do vírus na proximidade do gene, gerando um oncogene denominado $c$-myc. A transdução do gene $m y c$ pelo retrovírus gera um oncogene viral $v$-myc que remove sua unidade normal de transcrição (Beatty, 2014; Rezanka et al., 1992).

As inserções provirais do FeLV nas regiões do gene bmi-1, codificadas por flvi-2 e pim-1 são comumente afetadas em linfomas que também contêm v-myc e são descritos como 'colaboradores do gene myc' (Fujino et al., 2008; Levy et al., 1993). O Flit- 1 tem um papel importante no desenvolvimento de linfomas tímicos e parece representar um novo domínio de SIC proviral para o FeLV. A inserção está associada com a superexpressão de um gene celular, como o receptor de ativina A tipo II like 1 esse gene codifica um receptor na superfície da célula para a superfamília do fator de crescimento transformador beta -TGF (Fujino et al., 2008).

Os fibrossarcomas associados ao FeLV são causados pelo Vírus do Sarcoma felino (FeSV), um vírus recombinante que se desenvolve de novo em gatos infectados com FeLV-A pela recombinação do genoma do FeLV-A com oncogenes celulares (Besmer et al., 1986). Por um processo de recombinação genética, o FeLV adquire um dos vários oncogenes como fes, fms,fgr, alb e kit (Besmer et al., 1983). Como resultado, o FeSV é um vírus agudamente transformador e causador de tumor, causando uma malignidade policlonal com tumores multifocais surgindo simultaneamente após um curto período de incubação (McDonald et al., 1976; Pedersen et al., 1984). Os fibrossarcomas causados pelo FeSV tendem a crescer rapidamente, frequentemente com múltiplos nódulos cutâneos ou subcutâneos que são localmente invasivos e metastizam para o pulmão e outros locais (Pedersen et al., 1984).

Outra consequência de grande importância clínica em gatos infectados por FeLV é a imunossupressão, que promove uma diminuição dos mecanismos de vigilância tumoral causando um aumento indireto do risco do desenvolvimento de tumor. A imunossupressão aparentemente é específica para linfócitos $\mathrm{T}$ e particularmente linfócitos $\mathrm{T}$ helper ou $\mathrm{CD}^{+}$e linfócitos $\mathrm{T}$ supressores ou CD8 ${ }^{+}$(Hartmann, 2012b). Outro achado comum é a falha de linfócitos $\mathrm{T}$ helper, que causa uma vigilância tumoral ineficaz das células pré neoplásicas e neoplásicas portadoras de FOCMA (Rojko \& Olsen, 1984).

\section{Considerações finais}

Os estudos sobre a mutagênese insercional, concomitantemente, com a evidenciação dos locais que ocorrem SIC do FeLV são muito importantes para a identificação de genes envolvidos no desenvolvimento do linfoma. Esclarecendo o mecanismo da oncogênese causada pelo FeLV e avaliando dados 
epidemiológicos sobre a ocorrência e prevalência do FeLV no Brasil, há uma necessidade urgente de política eficaz para o controle e a prevenção, através da vacinação contra esse retrovírus na população de felinos domésticos. Além disso, são necessárias mais pesquisas em torno desse vírus e a infecção concomitante com outros vírus como o vírus da imunodeficiência felina e os herpesvírus. O Brasil, diferente dos países da Europa, Estados Unidos e Japão vive uma epidemia alarmante do FeLV e saber mais sobre o vírus tanto no aspecto epidemiológico, quanto sobre seu comportamento biológico é fundamental para a evolução da medicina felina na erradicação do vírus e na oferta de melhor qualidade de vida aos gatos que são portadores desse retrovírus.

\section{Referências}

Abrams, H. D., Rohrschneider, L. R., \& Eisenman, R. N. 1982. Nuclear location of the putative transforming protein of avian myelocytomatosis virus. Cell, 29(2), 427-439.

Beatty, J. 2014. Viral causes of feline lymphoma: Retroviruses and beyond. The Veterinary Journal, 201(2), 174-180.

Besmer, P., Hardy Junior, W. D., Zuckerman, E. E., Bergold, P., Lederman, L., \& Snyder Junior, H. W. 1983.The Hardy-Zuckerman 2$\mathrm{FeSV}$, a new feline retrovirus with oncogene homology to Abelson-MuLV. Nature, 303(5920), 825-828.

Besmer, P., Murphy, J. E., George, P. C., Qiu, F., Bergold, P. J., Lederman, L., . . Hardy, W. D. 1986.A new acute transforming feline retrovirus and relationship of its oncogene vkit with the protein kinase gene family. Nature, 320(6061), 415-421.

Coelho, F. M., Maia, M. Q., Luppi, M. M., Costa, E. A., Luiz, A. P. M. F., Ribeiro, N. A., . . . Resende, M. 2011.Ocorrência do vírus da leucemia felina em Felis cattus em Belo Horizonte. Arquivo Brasileiro de Medicina Veterinária e Zootecnia, 63(3), 778-783.

Coffin, J. M. 1979.Structure, replication, and recombination of retrovirus genomes: some unifying hypotheses. Journal of General Virology, 42(1), 1-26.

Cotter, S. M., Hardy Juniorr, W. D., \& Essex, M. 1975.Association of feline leukemia virus with lymphosarcoma and other disorders in the cat. Journal of the American Veterinary Medical Association, 166(5), 449-454.
Dorn, C. R. 1967.The epidemiology of cancer in animals. California Medicine, 107(6), 481489.

Essex, M., Cotter, S. M., Hardy Junior, W. D., Hess, P., Jarrett, W., Jarrett, O., . . Olsen, R. G. 1975.Feline oncornavirus-associated cell membrane antigen. IV. Antibody titers in cats with naturally occurring leukemia, lymphoma, and other diseases. Journal of the National Cancer Institute, 55(2), 463-467.

Essex, M., \& Snyder, S. P. 1973.Feline oncornavirus-associated cell membrane antigen. I. Serologie studies with kittens exposed to cell-free materials from various feline fibrosarcomas. Journal of the National Cancer Institute, 51(3), 1007-1012.

Forman, L. W., Pal-Ghosh, R., Spanjaard, R. A., Faller, D. V., \& Ghosh, S. K. 2009.Identification of LTR-specific small noncoding RNA in FeLV infected cells. FEBS letters, 583(8), 1386-1390.

Francis, D. P., Essex, M., Cotter, S., Jakowski, R. M., \& Hardy Junior, W. D. 1979.Feline leukemia virus infections: The significance of chronic viremia. Leukemia Research, 3(6), 435-441.

Fujino, Y., Ohno, K., \& Tsujimoto, H. 2008). Molecular pathogenesis of feline leukemia virus-induced malignancies: insertional mutagenesis. Veterinary Immunology and Immunopathology, 123(1-2), 138-143.

Gleich, S., \& Hartmann, K. 2009. Hematology and serum biochemistry of feline immunodeficiency virus-infected and feline leukemia virus-infected cats. Journal of Veterinary Internal Medicine, 23(3), 552-558.

Gleich, S. E., Krieger, S., \& Hartmann, K. 2009. Prevalence of feline immunodeficiency virus and feline leukaemia virus among clientowned cats and risk factors for infection in Germany. Journal of Feline Medicine and Surgery, 11(12), 985-992.

Gomes-Keller, M. A., Tandon, R., Gönczi, E., Meli, M. L., Hofmann-Lehmann, R., \& Lutz, H. 2006. Shedding of feline leukemia virus RNA in saliva is a consistent feature in viremic cats. Veterinary Microbiology, 112(1), 11-21.

Grant, C. K., Harris, D., Essex, M. E., Pickard, D. K., Hardy, W. D., \& Noronha, F. 1980. Protection of cats against feline leukemia virus-positive and virus-negative tumors by complement-dependent antibody. JNCI: 
Journal of the National Cancer Institute, 64(6), 1527-1533.

Hagiwara, M. K., Júnior, A. R., \& Lucas, S. R. R. 2015. Estudo clínico da infecção de felinos pelo vírus da leucemia felina em São Paulo. Revista Brasileira de Ciência Veterinária, 4(1), 35-38.

Hann, S. R., Abrams, H. D., Rohrschneider, L. R., \& Eisenman, R. N. 1983. Proteins encoded by $\mathrm{v}$-myc and c-myc oncogenes: identification and localization in acute leukemia virus transformants and bursal lymphoma cell lines. Cell, 34(3), 789-798.

Hardy Junior, W. D. 1981. The feline leukaemia virus. Journal of the American Animal Hospital Association, 17, 951-980.

Hardy Junior, W. D., McClelland, A. J., Zuckerman, E. E., Hess, P. W., Essex, M., Cotter, S. M., . . . Hayes, A. A. 1976. Prevention of the contagious spread of feline leukaemia virus and the development of leukaemia in pet cats. Nature, 263(5575), 326328.

Hartmann, K. 2005. FeLV treatment strategies and prognosis. Compendium on continuing education for the practicing veterinarian, 27 , 14-26.

Hartmann, K. 2012a. Clinical aspects of feline retroviruses: a review. Viruses, 4(11), 2684-2710.

Hartmann, K. 2012b. Feline leukemie virus infection. In C. E. Greene (Ed.), Infections dieseases of the dog and cat. Missouri, USA: Elsivier.

Hoover, E. A., \& Mullins, J. I. 1991. Feline leukemia virus infection and diseases. Journal of the American Veterinary Medical Association, 199(10), 1287-1297.

Hoover, E. A., Perigo, N. A., Quackenbush, S. L., Mathiason-DuBard, C. K., Overbaugh, J. M., Kloetzer, W. S., . . . Mullins, J. I. 1991. Protection against feline leukemia virus infection by use of an inactivated virus vaccine. Journal of the American Veterinary Medical Association, 199(10), 1392-1401.

Jackson, M. L., Haines, D. M., Meric, S. M., \& Misra, V. 1993. Feline leukemia virus detection by immunohistochemistry and polymerase chain reaction in formalin-fixed, paraffin-embedded tumor tissue from cats with lymphosarcoma. Canadian Journal of Veterinary Research, 57(4), 269-276.
Levy, J., Crawford, C., Hartmann, K., HofmannLehmann, R., Little, S., Sundahl, E., \& Thayer, V. 2008. American Association of Feline Practitioners' feline retrovirus management guidelines. Journal of Feline Medicine and Surgery, 10(3), 300-316.

Levy, J. K., Scott, H. M., Lachtara, J. L., \& Crawford, P. C. 2006. Seroprevalence of feline leukemia virus and feline immunodeficiency virus infection among cats in North America and risk factors for seropositivity. Journal of the American Veterinary Medical Association, 228(3), 371-376.

Levy, L. S., Lobelle-Rich, P. A., \& Overbaugh, J. 1993. flvi-2, a target of retroviral insertional mutagenesis in feline thymic lymphosarcomas, encodes bmi-1. Oncogene, 8(7), 1833-1838.

Linenberger, M. L., \& Abkowitz, J. L. 1995. Haematological disorders associated with feline retrovirus infections. Baillière's Clinical Haematology, 8(1), 73-112.

Lutz, H., Addie, D., Belák, S., Boucraut-Baralon, C., Egberink, H., Frymus, T., . . . Lloret, A. 2009. Feline leukaemia. ABCD guidelines on prevention and management. Journal of Feline Medicine \& Surgery, 11(7), 565-574.

McDonald, R., Thakkar, B., Wolfe, L. G., \& Deinhardt, F. 1976. Characteristics of three strains of feline fibrosarcoma virus grown in cat and marmoset monkey cells. International journal of cancer, 17(3), 396-406.

Mullins, J. I., Chen, C. S., \& Hoover, E. A. 1986. Disease-specific and tissue-specific production of unintegrated feline leukaemia virus variant DNA in feline AIDS. Nature, 319(6051), 333336.

Overbaugh, J., Donahue, P. R., Quackenbush, S. L., Hoover, E. A., \& Mullins, J. I. 1988. Molecular cloning of a feline leukemia virus that induces fatal immunodeficiency disease in cats. Science, 239(4842), 906-910.

Pacitti, A. M., Jarrett, O., \& Hay, D. 1986. Transmission of feline leukaemia virus in the milk of a non-viraemic cat. The Veterinary Record, 118(14), 381-384.

Pedersen, N. C., Johnson, L., \& Theilen, G. H. 1984. Biological behavior of tumors and associated retroviremia in cats inoculated with Snyder-Theilen fibrosarcoma virus and the phenomenon of tumor recurrence after primary regression. Infection and Immunity, 43(2), 631636. 
Pepin, A. C., Tandon, R., Cattori, V., Niederer, E., Riond, B., Willi, B., . . Hofmann-Lehmann, R. 2007. Cellular segregation of feline leukemia provirus and viral RNA in leukocyte subsets of long-term experimentally infected cats. Virus Research, 127(1), 9-16.

Persson, H., \& Leder, P. 1984. Nuclear localization and DNA binding properties of a protein expressed by human c-myc oncogene. Science, 225(4663), 718-721.

Poulet, H., Brunet, S., Boularand, C., Guiot, A. L., Leroy, V., Tartaglia, J., \& Minke, J. 2003. Efficacy of virus-vectored vaccine against feline leukaemia. Veterinary Record, 153, 141145.

Ramsay, G., Hayman, M. J., \& Bister, K. 1982. Phosphorylation of specific sites in the gagmyc polyproteins encoded by MC29-type viruses correlates with their transforming ability. The EMBO journal, 1(9), 1111-1116.

Rezanka, L. J., Rojko, J. L., \& Neil, J. C. 1992. Feline leukemia virus: pathogenesis of neoplastic disease. Cancer Investigation, 10(5), 371-389.

Rohn, J. L., Gwynn, S. R., Lauring, A. S., Linenberger, M. L., \& Overbaugh, J. M. 1997. Viral genetic variation, AIDS, and the multistep nature of carcinogenesis: the feline leukemia virus model. Leukemia, 10, 18671869.

Rojko, J. L., Hoover, E. A., Mathes, L. E., Olsen, R. G., \& Schaller, J. P. 1979. Pathogenesis of experimental feline leukemia virus infection. Journal of the National Cancer Institute, 63(3), 759-768.

Rojko, J. L., \& Kociba, G. J. 1991. Pathogenesis of infection by the feline leukemia virus. Journal of the American Veterinary Medical Association, 199, 1305-1310.

Rojko, J. L., Kociba, G. J., Abkowitz, J. L., Hamilton, K. L., Hardy, W. D., Ihle, J. N., \& O'Brien, S. J. 1989. Feline lymphomas: immunological and cytochemical characterization. Cancer Research, 49(2), 345351.

Rojko, J. L., \& Olsen, R. G. 1984. The immunobiology of the feline leukemia virus. Veterinary Immunology and Immunopathology, 6(1-2), 107-165.

Roy-Burman, P. 1996. Endogenous env elements: partners in generation of pathogenic feline leukemia viruses. Virus Genes, 11, 147-161.
Shelton, G. H., Grant, C. K., Cotter, S. M., Gardner, M. B., Hardy Junior, W. D., \& DiGiacomo, R. F. 1990. Feline immunodeficiency virus and feline leukemia virus infections and their relationships to lymphoid malignancies in cats: a retrospective study 1968-1988. Journal of Acquired Immune Deficiency Syndromes, 3(6), 623-630.

Snyder, H. W., Hardy, W. D., Zuckerman, E. E., \& Fleissner, E. 1978. Characterisation of a tumour-specific antigen on the surface of feline lymphosarcoma cells. Nature, 275(5681), 656658.

Soe, L. H., Devi, B. G., Mullins, J. I., \& RoyBurman, P. 1983. Molecular cloning and characterization of endogenous feline leukemia virus sequences from a cat genomic library. Journal of Virology, 46(3), 829-840.

Souza, H. J. M., Teixeira, C. H. R., \& Graça, R. F. S. 2002. Estudo epidemiológico de infecções pelo vírus da leucemia e/ou imunodeficiência felina, em gatos domésticos do município do Rio de Janeiro. Clinica Veterinária, 36, 14-21.

Sparkes, A. H. 1997. Feline leukaemia virus: a review of immunity and vaccination. Journal of Small Animal Practice, 38(5), 187-194.

Sykes, J. E., \& Hartmann, K. 2013. Feline Leukemia Virus Infection. In J. E. Sykes (Ed.), Canine and feline infectious diseases. Califórnia, EUA: Elsevier.

Torres, A. N., Mathiason, C. K., \& Hoover, E. A. 2005. Re-examination of feline leukemia virus: host relationships using real-time PCR. Virology, 332(1), 272-283.

Tsatsanis, C., Fulton, R., Nishigaki, K., Tsujimoto, H., Levy, L., Terry, A., . . . Neil, J. C. 1994. Genetic determinants of feline leukemia virus-induced lymphoid tumors: patterns of proviral insertion and gene rearrangement. Journal of Virology, 68(12), 8296-8303.

Weijer, K., Uijtde-Haag, F., \& Osterhaus, A. 1986. Control of feline leukaemia virus infection by a removal programme. Veterinary Record, 119, 555-556.

Recebido: 5 Setembro, 2018.

Aprovado: 25 Setembro, 2018.

Publicado: 26 Novembro, 2018.

Licenciamento: Este artigo é publicado na modalidade Acesso Aberto sob a licença Creative Commons Atribuição 4.0 (CC-BY 4.0), a qual permite uso irrestrito, distribuição, reprodução em qualquer meio, desde que o autor e a fonte sejam devidamente creditados. 